\title{
Values and Symbol of Pujawali (Perang Topat) Tradition for Halal Tourism
}

\author{
1Masniati \\ 1Mataram University, Mataram, Indonesia \\ masniati@gmail.com
}

\begin{tabular}{|c|c|}
\hline Article Info & Abstract \\
\hline $\begin{array}{l}\text { Article History } \\
\text { Received: July 12, } 2018 \\
\text { Accepted: September 30, } \\
2018\end{array}$ & \multirow{2}{*}{$\begin{array}{l}\text { This study investigated the values and symbols within the traditional festival } \\
\text { of Pujawali (Perang Topat) in West Lombok village of Lingsar and the } \\
\text { relation between the values and symbols and tourism. The "perang" or war } \\
\text { uses "ketupat" made from rice boiled in plaited coconut leaves as a weapon. } \\
\text { The existence of the tradition nowadays becomes more popular. This } \\
\text { tradition is not only about local celebration, but more about values and } \\
\text { symbols beyond it. This study employed descriptive qualitative method, using } \\
\text { interviews, observations and library research as techniques to collect data. } \\
\text { The interviewees were the older members of two communities of Hindu and } \\
\text { Muslim in Lingsar village. The finding indicated that Pujawali contains } \\
\text { values, including historical, religious, and social values, and contains symbols } \\
\text { of tolerance, brotherhood, and solidarity. The study suggests that the values } \\
\text { and symbol which are represented in the traditional festival reflect the } \\
\text { characteristics of Lingsar people-diverse but united. }\end{array}$} \\
\hline $\begin{array}{l}\text { Keywords } \\
\text { Pujawali; Values; Symbols; } \\
\text { Lingsar Village; Lombok; } \\
\text { Halal Tourism }\end{array}$ & \\
\hline $\begin{array}{l}\text { Support by: } \\
\text { doI Crossref }\end{array}$ & \\
\hline
\end{tabular}

\section{INTRODUCTION}

Lombok is one of Indonesia government -the designated priority for the halal destination. In Dubai 2015, one event of annual Muslim travel industry was dubbed Lombok as the best halal destination in the world. Since that day Lombok has become more popular as the halal tourism destination. Moreover, most Lombok people are Muslim, that's why people from all around the world have no doubt to visit Lombok to get halal food and to pray in a thousand mosques all around the island. As stated in https://www.npr.org/sections/parallels/2017/11/26/528010256/indonesia-aims-toattract-more-muslim-visitors-in-halal-tourism-push

About 2.7 million tourists visited halal destinations in Indonesia in 2016, according to a Tourism Ministry spokesperson, out of about 12 million foreign tourists in total. The greatest increase was seen in Lombok, which the ministry credits to halal tourism. Lombok welcomed about 3 million foreign and domestic tourists last year. On this island, nearly all the food - fish satay, chicken smeared with eponymous Lombok chili sambal - is already halal, and you're never more than five minutes from a mosque. Nearly every hotel, restaurant, and beach club has a musala, or prayer room. And since the island's population is mostly Muslim, the odds are that a tour guide for any activity - from trekking the volcanic Mount Rinjani to diving with sea turtles - can accommodate religious considerations.

Thus, as the priority destination of halal tourism, the people of Lombok should be prepared themselves to welcome the visitors by presenting all of the halal food along with the cultural events that are considered as the special characteristic of the island. The characteristic of the art, dance, festival, and ceremony which is representing the 
features of Lombok culture. One of a great festival and ceremony of Lombok is "Pujawali or Perang Topat" which is held in Pura Lingsar located in the district of Lingsar, West Lombok. It is a great event that representing a peace life between the two communities in Lingsar village. The two communities of two different religions of Bali and Muslim have lived in harmony since hundreds of years ago. The festival held once a year, on the full moon of the sixth of Hindu's calendar or on the seventh month of Sasak calendar.

Pujawali or Perang Topat is a war between Hindu community and Sasak Muslim community using "Topat", rice wrapped made of coconut leaves. The procession of Perang Topat begins in the evening before the D-day of the war, at this time, ladies from the two communities of Hindu and Islam has making ketupat and cook it till done. is used as the weapon of the war. The size of the made a little bit small to avoid hurting people at the war. When the flower of waru are falling down to the ground at half past five in the afternoon, the procession commences in which the people of the commoner and the prominent from the two communities surrounding "Purwadaksina" in the building of Kemalik. At once, a variety of art and dance showed to accompany the procession such as the famous Lombok traditional music and dance "Gendang Beleq" and the Batek dance. After that, the two communities of Hindu and Muslim converged on each point where the people of Hindus gathered at the Pura Gaduh temple yard, while the community of Muslim gathered at the Kemalik building. The war of throwing each other begin after one of the elders of each community throws each other for the first time. The war broke out where all of the people from the two communities are throwing each other followed by laughter and happiness that clearly emanated from their face.

According to Tuak Jamhur (Mr. Jamhur), the elder of Muslim community in Lingsar village, actually the ceremony of Perang Topat is the part of Pujawali where Pujawali is the procession to remember and flashback the journey of Shaikh Abdul Malik as the holy person who spread out the teaching of Islam in Lombok Island. For the Hindus, Pujawali procession is an adornment to the God of Siva which is repeatedly held every year.

There, the war is not just an annual ceremony but contains some values and symbols which background the events. The values and symbol usually following an event wherever it is as the history behind a certain great moment of every culture even in Pujawali ceremonial. Thus, every great event of one's culture is filled with values and symbols which stand for something and could evoke emotions and many different reactions. Therefore, the main purpose of this study is to find out the values and symbol which filled the events of Pujawali or Perang Topat. Also to investigate the relationship between that values and symbol with the concept of halal tourism as Pujawali or Perang Topat events is a great event to promote for the Halal Tourism.

\section{METHOD}

This paper conducted based on descriptive qualitative method. The descriptive qualitative method, employed in collecting the data that aims to describe the real condition of the field. According to Straus and Corbin (1998:11), the qualitative research is achieved that is not by means of statistical or quantification technique. The method can describe a complex detailed about a phenomenon in particular which is uneasy to describe using the quantitative technique. Wray (1998:8) also states that qualitative data deals with kinds of material such as judgments, perception, and insight. The primary source of the data is the events of Pujawali or Perang Topat procession in Pura Lingsar of Lingsar village, West Lombok, NTB. And the secondary data is the library research about the events. The technique of collecting data is through the 
interview the elders from the two communities of Hindus and Muslim, also the observation of the field and documentation.

\section{RESULT}

\section{Values in Pujawali or Perang Topat Festival}

There are some values found in Pujawali (Perang Topat), that historical, religious and social values filled the ceremony. According to the Hindus and the Muslim elder, the events can't be separated from the history of the construction of the temple of Pura Lingsar. The temple was built when Bali King Anak Agung the son of king Karang Asem, Bali ruled or colonized Lombok Island in the year $1759 \mathrm{M}$ (http//:www.wartantb.com). This is the forerunner of the conflict between Muslim of Sasak and Bali Hindus community. According to them, it was said that at that time the construction of the temple as a place of worship of Hindus got a rejection of Muslims. This rejection leads to the tension between the two people that came to the decision to a war. But before the war begins, a charismatic person called a kyai (sheikh, the person who teach the Quran and teach Islam) was to come and reconcile the two communities. The result of the counseled was both of the community decided to cancel the war and live in peace but to remember the moment, they decided to hold a ceremony which replaced the physical war with war. Since that time the tradition of the war is carried out each year to treat the memory of life pillars between Hindus and Muslims. Thus, in the area that used to war was build two building that is sacred by each community and named the sacred building of "Pura Begaduh" for the Hindus and the sacred building of "Kemalik" for the Muslim. Both of the building was construct intentionally as the symbols of concord between the two communities.

There, historical values of Pujawali event begin from hundreds of years ago when the kingdom of Karang Asem Bali has invaded Lombok. Thus the value history of Pujawali is has been saved and preserved by the people of Lombok as the foundation for the future generation. In this case historical knowledge of the Pujawali event as the crucial to protecting the tradition. The young generation of Lombok, especially Lingsar generation will have a foundation on which to build and know the history behind the event. And to protect the events by preserving authentic and meaningful documents, the places and the building of Pure Gaduh and Kemalik which is sacred as the important symbols of peace.

Moreover, the religious value in this event is insight immediately from the procession that involves the two communities which has different fate and believes or religion. Thus, the previous conflict is not only about the different tribe but also because of the different religion. However, in this event, everything that related to the religious differences is avoided and there only about respect and togetherness which is unity the two communities. Thus, as a value principle in the religious tradition where both of them work together to celebrate the great event every year and skim any wish that can trigger conflicts of belief or religion.

Furthermore, the social value has also filled the ceremony. Pujawali event has been constructing the social values of each person of the two communities where the experience of the event forms an important part of the culture of the society. Values account for the stability of social order of the Hindus and Muslim community. They provide the general guidelines to Lingsar people for social conduct. Values such as fundamental rights, patriotism, respect for each other, togetherness, and sacrifice. It is as a guide for their behavior in many ways. Also, assessing the events of how do people 
from different religions can work together in conducting that such ritual of Pujawali every year without compulsion and interfere with other outsiders.

\section{Symbols in Pujawali (Perang Topat) Procession}

Symbols are the sign that stands for something, that could be form in material objects and nonverbal communication. There are some nonverbal symbols found in Pujawali or Perang Topat festivals. The first one is the war itself or the activity of throwing each other is believe as the symbol of the physical war that changes into Perang Topat. Thus, the memory of the conflict has been changed into history and the community of Hindus and Muslim coexist and are united through a colossal war. They believe difference in religion if it is well managed could bring a blessing and prosperity for the Lingsar people. Also, in the war activity, we can see togetherness and equality between them. There are no more boundaries between the tribes of Sasak and Bali and no boundaries of religion between Hindus and Islam. Also, the nonverbal symbol is seen in the date where the event held every year in December or precisely the 15th day of the seventh month of Sasak calendar. The day is called "purnamasasih kepitu" or the full moon of the seventh month. While based on a Hindu Balinese calendar, coinciding with the 15th day of the 6th month called "Purnama Sasih Keenem"or on the full moon of the sixth month of Hindus calendar. This time means that on the night of the full moon is the right time for Hindus to perform the ritual of Pujawali, while for Muslims it is the right time to implement the flashback in the kamala building to commemorate the merits of an Islam teacher in Lombok Island named Raden Mas Sumilir.

Base on the elder of Muslim community, the Lingsar community believed that the place of Lingsar cannot be separated from the story of Raden Mas Sumilir. It is told, a time of Raden Mas Sumilir stuck his wand on the ground of Bayan. After his staff pulled out of the ground, there spurt a spring from the belly of the Earth. The Sasak language is in splattering water called "langser", then change become "Lingsar". Right after the spring water appears, Raden Mas Sumilir suddenly disappeared and make the people of the place came to grief. The sorrow then changes to happiness when Raden Pilling, the nephew of Raden Mas Sumilir come up and promise the people that Raden Mas Sumilir will come again and will appear in the site of the spring water. Various preparations made to welcome the emergence of Raden Mas Sumilir. and courses were prepared by the community. The time comes and Raden Sumilir actually present after the flowers of "waru" fall on the ground at around half past five in the afternoon. This is the background that represented the symbol of the time of a half past five in the afternoon, after the waru flowers falling to the ground in which this moment the charismatic Islam teacher has come back to the place of the springs and cured the longing of the Lingsar people who's miserable because of losing the mufti. However, after his appearance, the religious person disappeared again, otherwise, the people did not sad anymore because they were quite satisfied with the second meeting with Raden Mas Sumilir and since that time, the Lingsar people experienced prosperity in which the springs always fine to irrigate their rice field. There a blessing for the people with plentiful harvest and peace situation inside their soul.

Beside the nonverbal symbol, the object of material also symbolizes in the procession of Pujawali or Perang Topat. One of the material object symbols in this ceremony is the temple itself where there are two building which is sacred by the two communities, the Pura Gaduh is sacred by the Hindus and the building of Kemalik is sacred by the Muslim. Both of the building appears to be deliberately constructed as a symbol of Concord between Hindus with Muslims that has lasted since the era of the Karang Asem Kingdom. The other material symbol of the ceremony is the animal of Buffalo as the important animals. This animal is a symbol of Kyai Haji Sheikh Abdul 
Malik supplies while preaching. The selection of a Buffalo in the trace path not without reason. All based on the tolerance between people of Sasak and Hinduism. If using beef there is a fear that it would offend the Hindus as cows are animals of the venerable and respected among the Hindus. While, if it uses the pig it will make Muslims uncomfortable given the animal for Muslims is haram to eat.

\section{Values and Symbols of Pujawali (Perang Topat) and Halal Tourism}

The values of religious and historical in Pujawali has built the cultural perception of Lingsar people whereas both of the community work together in maintaining the originality of the place. In Pura Lingsar, the place of Perang Topat is keeping by the two different keepers of the Pura Gaduh and the Kemalik building. In this area, the visitor and the local people are not allowed to take an alcoholic drink or doing a forbidden activity such as gambling and drinking drugs and alcohol. This principle is in line with the Halal principle of the Muslim regulation of sharia. Moreover, the symbol of the nonmaterial and material object in the Pujawali procession showed that there is a balance between the two believers seen in the trace path made when surrounding the temple escort the animal of buffalo. The buffalo choose to avoid the use of Fork which is forbidden or Haram for the Muslim to consume. In this case, the buffalo slaughtered in Muslim way and the meat is Halal food to consume for the Muslim Visitor and for the non-Muslim visitor as well.

\section{CONCLUTION}

The procession of Pujawali or Perang Topat is filled with so many values and symbol which is appropriate to consider for the Halal tourism events. The events include some traditional music and dance as the special characteristic of Lombok culture. People all around the world have been visiting this site and today time to the Muslim tourist to visit the place, especially in December in order to get involved in the procession of Pujawali and Perang Topat. Don't be worry about the food and the place, because all the food (sesaji) is made by the Muslim people and the place of the ceremonial is free from Haram activities. Last but not least, as the keeper of the Kemalik said when interviewed, "Pujawali or Perang Topat adalah bersatu tetapi bukan menyatu, terpisah tapi tidak bisa dipisahkan" which means that the procession is conducted together by the two communities of Hindus and Muslim and owns the place together, however the Pura Lingsar is the place of praying only for the Hindus not for the Muslim. Even though they cannot be separated as they are tied by the history to celebrated the memory of the Sheik Abdul Malik for the preaching and to the "Batara Siwa" (the God of water) for the Hindus which brings prosperity and wealthy for Lingsar people.

\section{REFERENCE}

[1] Axtell, R.E, 1998. Gestures: The Do's and Taboos of Body Language around the World: Jhon Wiley, New York

[2] Biedermann, H. 1990. Dictionary of Symbolism. Oxford: United Kingdom

[3] Cassirer E. 1923. The Philosophy of Symbolic Forms: Yale University Press

[4] Graeber. 2001. Toward an Anthropological Theory of Value (The False Coin of Our dreams): Palgrave: Mac Milan: New York

[5] Leeuwen.T.V.2005. Introducing Social Semantic. Routledge: New York

[6] Smith. J.L. in Gibson and Pendlebury 2009.Valuing Historic Environment: Ashgate Publishing Company: England

[7] Wittgenskin.1998. Culture and Value: Second Edition: Blackwell Publisher: USA

[8] https://www.npr.org/sections/parallels/2017/11/26/528010256/indonesia-aimsto-attract-more-muslim-visitors-in-halal-tourism-push 
[9] http://www.wartantb.com/perang-topat-tradisi-unik-suku-sasak/

[10] https://www.huffingtonpost.co.uk/muhammad-Zulfikar-rakhmat/halaltourism-an-importan_b_12229662.html 